\title{
Data Analysis of Shipping Cycle in Dry Bulk Market
}

\author{
Jin Yang \\ ${ }^{1}$ School of Navigation, Jimei University, Xiamen, China \\ Correspondence: Jin Yang. E-mail: 1713084222@qq.com
}

Received: July 9, 2020

Accepted: August 19, 2020

Online Published: July 31, 2021

doi:10.5539/ass.v17n8p1

URL: https://doi.org/10.5539/ass.v17n8p1

\begin{abstract}
The dry bulk market BDI index fell from 11,793 points on May 20, 2008 to 290 points on February 10, 2016, which is a very certain "downward cycle" of the shipping market, showing an "L" shape. By citing random samples and big data, the paper analyzes the causes of the "L" type cycle. First, through random sample data, a binary measurement model with BDI index as the dependent variable and dry bulk market supply and demand as independent variables is established, and it is concluded that the "down cycle" of the dry bulk market is caused by the "supply factor"; then the paper continues to quote big data, that is, to use "whole sample" to further analyze the sub-variables of supply variables. Finally, the paper concludes that the "downward cycle" of the dry bulk shipping market is "L" shaped, which is caused by changes in the "market structure" of the shipbuilding market.
\end{abstract}

Keywords: data analysis, dry bulk market, shipping cycle

\section{Introduction}

On May 20, 2008, The BDI index (Baltic Dry Index, BDI for short), a dry bulk freight rate indicator which measures whether the prosperousity of global shipping market, is closed at a daily high of 11,793-point. However, the BDI index has been affected by the US subprime mortgage crisis since December 12, 2008. The daily plunge to 764-point at the daily close. Since then, it has continued to fall for 8 years, until the BDI index hit a daily close of 290-point on February 10, 2016. The BDI index has created the lowest point since its creation in January 1985, and has made the BDI index forms a long "L" type periodic curve (BDI Index Chart) (see Figure 1). With the continuous decline of the BDI index, the operating performance of shipping companies, especially those operating dry bulk shipping at sea, has deteriorated. In the early days, many dry bulk shipping companies have been forced to take various measures to deal with the depression of the shipping market. These measures are mainly the traditional idle ships, the bankruptcy and reorganization of the dry bulk shipping companies. Most scholars thought that the nature of this shipping down cycle is only a traditional cyclical adjustment, and the adjustment cycle is only about four years. For example, in 2009, Chinese shipping scholars and experts Wang Pei, Ren Ying (Wang \& Ren, 2009), Ma Shuo (Ma, 2009) believes that the global shipping down cycle is caused by the US Subprime Mortgage Cycle and proposed strategies such as Cash is king and Mergers and Reorganizations. In 2010, aiming at the Subprime Mortgage Cycle in the United States in 2010, the rescue of various countries triggered the recovery of the shipping market. Many shipping companies and experts believed that the shipping market had entered the era of the shipping upward cycle, and had proposed strategies for the adjustment and transformation of the shipping upward cycle structure such as Liao Chuanbo (Liao, 2010), Wei Jiafu (Wei, 2012). However, after the BDI index briefly rebounded to 4078-point, it continued to decline. By February 10, 2016, the BDI index fell to a historic low of 290-point. At this time, the shipping market fell into a more severe depression. A large number of dry bulk ships were dismantled and sold as scrap iron (Zhao, 2012). The shipping market continued to report the news of the closure of shipping companies (http://www.ship.sh/attachment/images/201508/2015082613/2015-9-3/2018-2-1). Many scholars have begun to consider the reasons for the low BDI index (Xing, 2012). Scholars in the shipping industry from various countries again discussed the Rescue Policy of the shipping industry. This discussion is mainly about whether the dry bulk shipping market is Destocking or De-capacity. Based on the theory of derived demand and using dry bulk market data, Jin Yang calculated that between 2012 and 2014, there was a huge gap between the supply of the shipping market and the real demand, that is, there was a severe oversupply in the shipping market, and the shipping market tended to adopt De-capacity policy (Yang, 2013). Many large shipping companies refuted that the Contrarian Shipbuilding strategy around 2010 (http://finance.eastmoney.com/news/134420120830248537 
223_3.html). Moreover, the depression of the shipping dry bulk market has spread from the dry bulk market to the container liner shipping market. On the morning of August 31, 2016, Hanjin Shipping announced that the board of directors had passed without objection and decided to apply for bankruptcy (Hanjin Shipping Declared Bankruptcy). Until February 10, 2016 the BDI index of the dry bulk market began to climb slowly after falling to 290-point. From 2008 to 2016, the dry bulk shipping market formed a perfect Shipping down cycle, that shows as ' $\mathrm{L}$ '. Compared with the traditional cycle, ' $U$ ', there is a serious paradox.

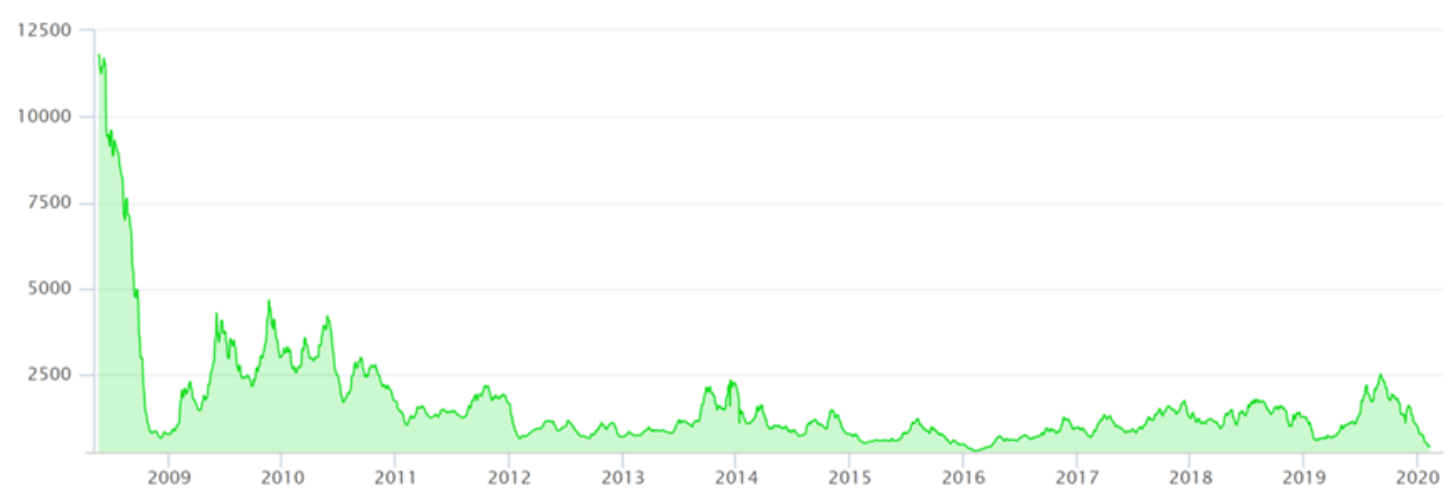

Figure 1. BDI Index Trend Chart during 2008-2020

(This graph shows that the BDI index appeared in the "U" cycle theory of anti-traditional economics from 2008 to 2020 , thus becoming the paradox of the theory of the traditional economic cycle.)

Aiming at the paradox generated by the "down period" of the BDI index curve, this paper introduces "random sample" and "big data" analysis methods to explain and analyze the reasons for the paradox. The first step is to find the reasons in the terms of supply and demand why the BDI index showing as ' $\mathrm{L}$ '. The paper establishes a binary model with BDI index as the dependent variable, supply variable and demand variable as the independent variables, compares the motivations of the dependent and independent variables for the BDI index volatility, and finds the main variable and the secondary variable. In the second step, the paper focuses on the main variables, conduct whole sample or big data analysis, and further analyzes the sub-Svariables of the main variables to find the main reason for the ' $L$ ' paradox of the shipping cycle with the big data method.

\section{The Supply and Demand Measurement Analysis During the Shipping Down Cycle}

The paper is based on the theory of supply and demand in the shipping market, and uses the data from the "down cycle" of the dry bulk market from 2008 to 2016 as a tool to establish a binary measurement regression, of which the BDI index as the dependent variable and the two variables of supply and demand as the independent variables.

\subsection{Econometric Model}

According to the theory of supply and demand equilibrium in the dry bulk market, supply and demand jointly determine the freight rate in the dry bulk market, and the following dual econometric model is obtained, as shown in equation (1).

$$
Z S D S=\beta_{0}+\beta_{1} H Y M Y+\beta_{2} C H B O+\mu
$$

among them,

ZSDS stands for BDI index, unit: point;

HYMY represents shipping demand (or shipping trade), unit: 100 million tons;

CHBO stands for shipping supply (or gross tonnage of the ship) in 100 million deadweight tons;

$\mu$ is an immediate disturbance item; $\beta_{0}$ is a constant term.

\subsection{Data Source}

The ZSDS data comes from Eworldship. The paper takes the arithmetic average of the 12 months of the BDI dry bulk index, that is, the 12 months of data are accumulated every year, then divides the accumulated results by 12 to obtain the BDI dependent variable data for each year from 2000 to 2017

The shipping demand, HYMY data is derived from the UN Maritime Commission database. Maritime trade data in the dry bulk market from 2000 to 2017 are collected in the database; 
The shipping supply, CHBO data is derived from the UN Maritime Commission database. Collect the data of dry bulk ships in the dry bulk market in each year from 2000 to 2017 in the database and input the data of each year into the SPSS software.

\subsection{OLS Results}

According to the spss input results, equation (1) is obtained, where the fittness of the model $R^{2}$ is 0.904 , and the sig value is zero, indicating that the goodness of fit of the equation is significant. Finally, the $T$ test of each coefficient is greater than 2 , and the sig value is zero, indicating that the coefficient values are significant. Therefore, the OLS results are shown in Table 2:

$$
\begin{gathered}
\operatorname{Ln}(Z S D S)=0.172 H Y M Y-1.282 C H B O+4.126 \\
(8.759) \quad(-10.427) \quad(7.646) \\
R^{2}=0.904 \quad \mathrm{~N}=17
\end{gathered}
$$

The $\mathrm{T}$ test in the brackets of equation (2) is not tested. After conversion, the equation (3) is as follows:

$$
Z S D S=e^{0.172 H Y M Y-1.282 C H B O+4.126}
$$

The economic significance of equation (3) shows that: First, the impact of the supply and demand of the dry bulk market on the freight rate index BDI is a geometric progression, that is, every 100 million tons of dry bulk market demand will make the BDI index increases by 0.47 -point (or $\mathrm{e}^{0.172}$ ). For every 100 million dwt increase in ship supply, the BDI index will decrease by $\mathrm{e}^{1.28}$ (or 3.47) points. A slight fluctuation in supply and demand on the dry bulk market will leading to the ups and downs of the BDI index. It can be seen that the huge fluctuation of the BDI index is due to the joint effect of supply variables and demand variables.

\subsection{The Economic Significance of the Model}

If the equation (3) is converted into the following equation (4), its economic significance can be clearly observed:

$$
B D I=e^{0.172 \text { demand }-1.282 \text { supply }+4.126}
$$

First, the relationship between the BDI index and the supply and demand of the shipping market is a geometric progression. As we can see, the influence of the demand on the BDI index is not as great as the supply, since the coefficient of demand is 0.172 , which is less than 1 , it indicates that the impact of demand on BDI is relatively small;

Second, from the equation (4), we can see the coefficient of supply is 1.282 , which is greater than 1 , it indicates that the impact of supply on BDI is large;

Third, the degree of influence per unit of demand variable is 0.47 ; the degree of influence per unit of supply is 3.47. The ratio between them is 7.38 times. That is, the impact of supply variable on BDI is 7.38 times that of demand variable.

According to the economic significance of the model, the reason why the paper puts the BDI index into the "L" shape in the downward cycle from 2008 to 2016 is due to the supply of the shipping market. Therefore, this paper further focuses on the analysis of subvariables in supply variables.

\section{Analysis of Shipping Down Cycle}

Through the analysis of the econometric model of the random samples of equation (4), it is concluded that the main reason for the "down period" being "L" is caused by supply variables. Because there are many sub-variables of supply variables, in order to find the exact subvariables in supply variables and narrow the scope of research, the paper applies big data analysis, that is, the whole sample analysis method, to further analyze it.

\subsection{Ship Financing Is Not the Reason of "Down Period"}

Among the sub-variables of supply variables, ship financing is often a key sub-variable in supply variables. Shipping economics has an important analysis of ship financing. Therefore, when studying supply variables, one cannot give up the analysis of ship financing. The paper collects the top 40 banks with the largest ship financing in the world, and counts the ship financing amount of these banks in time series to form an overall sample of ship financing. According to the statistical results of all "ship financing" of the world's top 40 banks: from 2008 to 2016, the total amount of ship financing of the world's top 40 banks for the shipping industry totaled US $\$ 355.25$ billion (Petrofin Bank Research). This paper is based on the ship financing in 2008, and the ship financing in each year is compared with that in 2008.

The results show that the amount of ship financing of the world's 40 largest sample banks has declined year by 
year. As of 2017, it has actually declined by $25 \%$. In the same period, from 2008 to 2017, the supply of ships is still based on 2008, and the global supply of ships is increasing year by year. By 2017, the supply tonnage of ships had increased by $28 \%$ (Figure 2). That is to say, in the "down cycle" of the shipping market from 2008 to 2016, ship financing and ship supply showed a "negative correlation". That is, in the "down cycle" of 2008 to 2016, although the proportion of ship supply increased year by year, the amount of ship financing is decreasing year by year. Therefore, the paper believes that ship financing has no significant impact on the "down cycle" of the shipping market from 2008 to 2016.

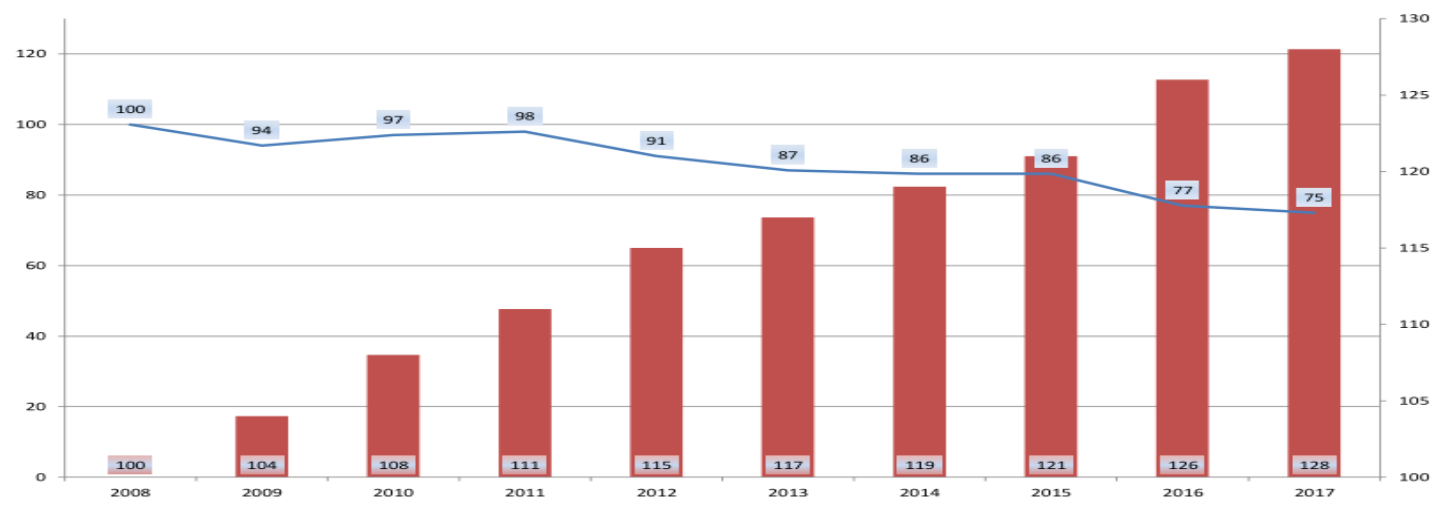

Figure 2. Ship Financing Index and Fleet Size Index of the World's Top 40 Banks

(This chart indicates an increase in the supply of shipping, rather a decline in ship financing, which is not the cause of the increase in fleet size or shipping supply.)

\subsection{Market Structure Is the Main Reason Leading to the "Shipping Down Cycle" of the Shipping Market}

Since "ship financing" is not a key sub-variable with an "L" downward cycle, the paper still quotes big data to analyze the changes in the "market structure" of the shipbuilding market. The paper analyzes all the market players in the shipbuilding market, China, Japan and South Korea. As the global shipbuilding market share of these three market players reaches $90 \%$, the global shipbuilding market is completely controlled by China, Japan and South Korea. The shipbuilding market has reached to the classic pattern named "oligopolistic market". The paper further studies the changes in the internal market structure of the three oligarchs during the "down cycle" from 2008 to 2016 and finds that China and South Korea's global market share was relatively high in 2013 and Japan's share was relatively low; but after 2018, Japan's market share has increased from $18.7 \%$ in 2013 to $24.9 \%$ in 2018. In six years, Japan's market share has increased by $6.2 \%$, while China and South Korea's market share has declined year by year. This period happened exactly during the "down cycle" of the shipping market. According to the "Cournot Model" theory in economic principles, when the oligopolistic market is in equilibrium, the market share of each oligarch is generally balanced (or equal).

When an oligarch market does not achieve equilibrium, each oligarch will compete fiercely and contrive to achieve equilibrium, including lowering prices and dumping to increase the market share of each oligarch. As a result, this price reduction and dumping, the supply of the shipping market will increase a lot, which will affect the shipping market's sharp drop in freight rates. Then after falling to a certain level, that is, after the market has reached equilibrium, the supply will remain at a certain level without fluctuations (see Table 1), and the market share of the three oligarchs will be about $88 \%$. Since the supply in the shipping market has been fixed at this level for a long time, after the BDI in the shipping market drops sharply, a horizontal curve is formed, that is, the BDI index in the shipping market presents an " $\mathrm{L}$ " curve.

Table 1. China, Japan, and Korea

\begin{tabular}{ccccc}
\hline Years & $\begin{array}{c}\text { China } \\
(\%)\end{array}$ & $\begin{array}{c}\text { Japan } \\
(\%)\end{array}$ & $\begin{array}{c}\text { Korea } \\
(\%)\end{array}$ & $\begin{array}{c}\text { Three Countries' Shipbuilding Completions Account } \\
\text { for the Global Share }\end{array}$ \\
\hline 2013 & 35.2 & 18.7 & 34.2 & 88.1 \\
2014 & 33.2 & 18.9 & 34.6 & 86.7 \\
2015 & 35.1 & 18.1 & 34.6 & 87.8 \\
2016 & 32.0 & 20.4 & 35.4 & 87.8 \\
2017 & 34.5 & 20.3 & 31.8 & 86.6 \\
\hline
\end{tabular}




$\begin{array}{lllll}2018 & 37.1 & 24.9 & 25.5 & 87.5\end{array}$

Source: Clarkson Research UK https://www.clarksons.com/services/research/2020-2-1

This table shows the percentage of each countries-China, South Korea and Japan's shipping completions account fot the global share from 2013 to 2018 . China, South Korea and Japan are the main suppliers of ships worldwide. It can be seen that the ship supply market is a classic oligarch monopoly market. The theory of free competition in the traditional shipping market, such as the cycle shape in the cycle theory, is no longer the "U" type, but the "L" shape appears.

\section{Conclusion}

In this paper, a certain shipping downlink period is analyzed by two methods: Big Data and random samples. In this paper, we set up a bivariate econometric model with BDI index as dependent variable and supply and demand as independent variables, and input the random data model from 2000 to 2017. This paper makes a big data analysis on the factors of supply variables.

Firstly, it analyzes the whole sample of ship finance of 40 big banks in the world. It finds that the number of ship finance of 40 big banks in the world has decreased by $25 \%$ during the fixed period, this paper continues to use the big data analysis to analyze the market structure of the shipping market. Big Data analysis was conducted for China, Japan and South Korea, three countries that account for 90 per cent of the global market in ship building completions. It finds that the shipbuilding market is changing its market structure in a certain period of time. Among the three oligarchs, Japan achieved equilibrium in the shipbuilding market by pursuing market share growth from 18 per cent in 2013 to 24.9 per cent in 2018, as Japan had the lowest market share.

Therefore, the paper argues that, the dry bulk market from 2008 to 2016, the downward cycle is caused by the changes in market structure. The advantage of the model is that the structural change of the shipping market from 2008 to 2018 is explained, and the reason of the structural change of the shipping market is the supply market, that is, the huge increase of the shipbuilding market efficiency. The determination of the model mainly reflects that the number of samples is limited by the research time and the number of samples is too small. But the conclusion of the model for the economic significance of the shipping economic supply and demand model is mainly reflected which is elaborated below:

First, in the fusion of the supply and demand sides of the shipping market, the efficiency of the supply side or the shipbuilding market is greatly improved, can cause the market supply and demand structure to change, then causes the shipping market freight rate index of Bdi huge fluctuation; The supply side usually deals with the changes of market structure by means of "group heating", and this kind of "group heating" inevitably leads to the changes of market structure, which makes the market structure of shipping market change from smonopoly competition to oligopoly, even monopoly transformation, thus causes the market BDI index to have the violent fluctuation. Therefore, from another side reflects the shipping market freight rate volatility, is often a drastic change in the market structure.

In the future, the shipping market structure will be stable when the above changes are completed. No matter whether the external shock of shipping market is severe or not, the fluctuation of both supply and demand should not change greatly, so the probability of the huge fluctuation of BDI index should tend to converge.

\section{References}

Another Domestic Shipping Giant in the Shipping Industry, Nanqing Company, may be Closed Down. Retrieved from http://www.ship.sh/attachment/images/201508/2015082613/2015-9-3/2018-2-1

BDI Index Chart [EB/OL]. Retrieved from http://value500.com/BDI.asp/2018-02-20

COSCO again Suffered Huge Losses in the First Half of the Year, and the 4.8 Billion Expansion Fleet was out of Date. Retrieved from http://finance.eastmoney.com/news/1344, 20120830248537223_3.html

Hanjin Shipping Declared Bankruptcy. Retrieved from http://www.eworldship.com/html/2016/ShipOwner_0901/119275.html/2018-2-13

Liao, C. B. (2010). Strategic Analysis of Shipping Down Cycle after Liner Company Cracked it. Engineering Science and Technology, (3), 77-78.

Ma, S. (2009). The Theory of Shipping Market Cycle and the Current Changes of dry Bulk Shipping Market. Water Transport Management, (11), 15-17.

Petrofin Bank Research. Retrieved from https://www.petrofin.gr/management/2020-2-1 
Wang, P., \& Ren, Y. (2009). Ways to Resolve the Shipping Down Cycle. Import and Export Manager, (2), 42-43.

Wei, J. F. (2012). The International Shipping Market is in Five Major Mimbalances. Port Economy, (1), 29-30.

Xing, D. (2012). Reflections on a new low BDI Index. China Ship Inspection, (2), 13-15.

Yang, J. (2013). "Destocking" or "De-capacity" in the dry Bulk Market?. China Navigation, (4), 130-134.

Zhao, F. F. The Situation of Foreign Trade is Severe, the Profits of Shipping Companies are Greatly Reduced, and Some Ships are Sold as Scrap Steel. Retrieved from http://finance.ifeng.com/news/industry/20120824/6935915.shtml/2012-8-24

\section{Copyrights}

Copyright for this article is retained by the author(s), with first publication rights granted to the journal.

This is an open-access article distributed under the terms and conditions of the Creative Commons Attribution license (http://creativecommons.org/licenses/by/4.0/). 